\title{
Determinants of International Migration in Pakistan
}

\author{
Muhammad Farooq \\ Associate Professor, Department of Sociology \& Anthropology, Pir Mehr Ali Shah \\ Arid Agriculture University, Rawalpindi \\ Shahnaz Tarıq \\ Chairperson, Department of Sociology Bahauddin \\ Zakariya University, Multan \\ Firdous Gulzar \\ Assistant professor of Sociology, \\ Government College Women University Faisalabad
}

Faria Ibad Mirza

Lecturer, Department of Sociology \& Anthropology, Pir Mehr Ali Shah Arid

Agriculture University, Rawalpindi

Fara Riaz

Lecturer, Institute of Rural Home Economics, University of Agriculture Faisalabad

\section{Doi:10.5901/mjss.2014.v5n20p2028}

\section{Abstract}

This study was designed to examine the determinants of international migration which were inspired/compelled the people of lower wages countries to higher wages countries in order to improve their socio-economic status at origin. The movement of labor from agricultural and sick industrial sectors is a universal phenomenon which is affiliated of economic modernization and development. Traditional migration models overlook many potential interactions between migration and development. In Pakistani society, the poor economic opportunities, resources inequality and demographic behaviour are the main determinants of international migration. The main objective of this study was to explore the relationship between the Socio-economic status of the respondents and determinants of international migration. The present study was carried out in Faisalabad cit and four Tehsils of Faisalabad District (Faisalabad, Jaranwala, Thandlianwala and Samundri). Both the urban and rural areas were consisted of eight circle areas from the city and eight villages from four tehsiles. Basic census was done by the researcher to draw the sample. Six hundred respondents were interviewed from eight circle areas of the city and eight villages from four tehsiles. Probit model technique proved that individuals from less resources communities were migrated to Middle East and European countries in order to improve their household income.

Keywords: determinants of international migration, rural and urban people, push and pull factors, Probit Model

\section{Introduction}

International migration in Pakistan nowadays is becoming one of the most obvious as well as influential social factors, which is profoundly changing the current social system, economic system and the society as a whole. Migration from under-developing countries and particular from Pakistan to abroad may take place because agricultural and sick industrial sectors are unable to provide livelihood to the people and village living condition may be intolerable. Human beings have been moving from poor to rich countries in connection with getting better economic opportunities and some extent to educational facilities. Johnson (1948) claims that rural out-migration to European and Middle East counties as solution to surplus labor and low incomes in agriculture field. As a matter of fact, more than 150 million international migrants 
celebrated the turn of the millennium outside their countries of birth. They came to their new country to work, study, join their family, or escape persecution or violence in their home countries (IOM, 2000). While in Pakistan 7\% and 3\% of the migrants from the total population are settled in the big cities of their countries and abroad (Census, 1998). In looking at the causes of international migration, the key question is why certain people move while human nature appears so strongly to mitigate uprooting. This is the consequence of economic globalization and market penetration (IOM, 2000). Thus, some of the surplus agricultural population, skilled population and non-skilled population have moved to the Middle East and European countries and consequently they put pressure on the civic institutions of these countries. On the positive side, international migration may help reduce pressure on agricultural and industrial sectors, provide positive opportunities for the Pakistani unemployed and underemployed, and also raising their living standards and livelihood prospects at the household and community levels in urban as well as rural areas in Pakistan. On the negative side, some of the semi skilled population and non-skilled population have moved toward abroad and consequently shortage the labour in agricultural and industrial sectors put pressure on the civic institutions and also generates a problem of housing at destination. Decision making for international migration is always based on Push and pulls Factor which are addressing by Lee's Push-pull theory. This theory divides factors causing migrations into two groups: Push and pull factors. Push and pull factors are those factors which either forcefully push people into migration or attract them to an area.

\subsection{Push Factors}

Not enough jobs, Few opportunities, Primitive conditions, Desertification, Famine or drought, Political fear or persecution, Poor medical care, Loss of wealth, Natural disasters, Death threats, Slavery, Pollution, Poor housing, Discrimination, Poor chances of marrying

\subsection{Pull Factors}

Job opportunities, Better living conditions, Political and/or religious freedom, Enjoyment, Education, Better medical care, Security, Family links, Industry, Better chances of marrying. However, Researcher concludes those factors which are applicable in Pakistani society.

\subsection{Push and Pull Factors}

(i) Decline in the per capita share in the resources such as agricultural land and stagnating agriculture, change in technology, exhaustion of mines, timber or other resources and closure of certain industries in some of the regions.

(ii) Reduction in employment due to mechanization.

(iii) Social, political and caste discrimination.

(iv) Availability of job and better working condition, higher wages, better sanitation, transportation and communication facilities.

(v) Better opportunities for education, better standard of life, marriage freedom, safety and security, political awareness of the people of ones own choice.

(vi) Better health and recreational facilities for all type of people.

\section{Materials and Methodology}

The present research was conducted in Faisalabad city and four Tehsils of Faisalabad District (Faisalabad, Jaranwala, Thandlianwala and Samundri). Both the urban and rural areas are consisted of eight circle areas from the city and eight villages from four tehsiles. In order to draw the sample from the Faisalabad city, survey lists maintained by Excise and Taxation Department were used as the sampling frame. A multi-stage sampling technique was used to draw the sample (Nachmias and Nachmias, 1992). At the first stage, Faisalabad city was selected which had already been divided into three Rating zones and thirty-eight circle areas by the Excise and Taxation Department on the basis of economic stratification. At the second stage, eight circle areas were selected i.e. Ghlum Muhammad Abad, Muslim Town, Peoples Colony No.2, Ayub Colony, Gulistan Colony and Madina town, Katchiabadi Rajwali, Aminabad and Nasir Colony through random sampling to observe the determinants of international migration on the individuals and family through decision making processes. At the third stage, basic census was completed by the researcher with the help of interviewers who 
had visited the research areas and sampling frame was constructed. Three hundred households were selected through random sampling technique from sampling frame. Thus, required informations were collected wherever the migrants had been living. Basic census was done by the researcher in the rural areas of district Faisalabad. This Basic census was used as sampling frame. Three hundred respondents were being taken from sampling frame from the eight villages, two villages from each Tehsil selected by simple random sampling technique. Simple percentage was applied to measure the respondents' tendency regarding decision making process for international migration. Probit Analysis technique was used to draw the inferences. Probit model is estimated through Statistical Packages for Social Sciences (SPSS).

\section{Results and Discussion}

Pakistan is a developing country that has experienced rapid international migration in the last forty years. This study examines the determinants of international migration generally from Pakistan and particularly in Faisalabad district. Simple percentage was applied to measure the respondents' tendency regarding decision making process for international migration. Probit model was used to test the following hypotheses.

\section{Determinants of Migration (Push and Pull Factors)}

Table 1: Push and Pull Factors for Migrants in the urban community

\begin{tabular}{|l|c|c|l|c|c|}
\hline Push Factors & Frequency & Percentage & Pull Factors & Frequency & Percentage \\
\hline Low paying jobs & 240 & 80 & High paying job & 210 & 70 \\
\hline Poor educational facilities & 39 & 13 & Educational facilities & 63 & 21 \\
\hline Poor rural setting & 21 & 7 & Health and marketing facilities & 27 & 9 \\
\hline Total & 300 & 100 & Total & 300 & 100 \\
\hline
\end{tabular}

Push factors refer to conditions at place of origin, such as decline in income opportunities, a scarcity of arable land and social discrimination, which encourage individuals to consider migration and to begin the search for alternative locations. Pull factors relate to conditions at the potential place of destination, which make them attractive place to work or live. Relatively high wages, widespread opportunities for self-employment, or civic amenities such as educational and health facilities are examples of pull factors. The findings in table 1 illustrate most preferable attitude of the respondents i.e. $80 \%$ and $13 \%$ of the respondents left their place of origin due to low paying job and Poor educational facilities, respectively. These findings coincide with Chaudhury (1980) who found that out-migration is generally higher from the villages characterized by land scarcity, unequal distribution of land, and high proportion of agricultural labour. Pull factors illustrate as the findings indicate that $70 \%$ of the migrants migrated from origin to destination for better employment with regard to enhance the household income, whereas $21 \%$ migrants left their origin for educational purposes. Moreover, $9 \%$ of the respondents reported that they were migrated to avail themselves for social facilities i.e. better health and better marketing facilities. Afsar (1995) argued that migrants often benefited more than non-migrants because of their innovative, risk taking and desperate nature. The benefits included higher or regular income, gain in wealth, greater access to public services and education.

\section{Empirical Results of the Model}

\subsection{Lesser the economic opportunities in the rural areas of Pakistan, greater the chance will likely be international migration}

Land holding is considered as economic opportunities in the rural areas of Pakistan. The most important aspect of the rural economic opportunity hypothesis states that land deprivation, particularly total landlessness or some small land holdings was a positive determinant for rural people to international migration. The land holdings coefficient was significant at $5 \%$ and $10 \%$ level in the rural communities but land holdings coefficient was negative in the urban communities. The negative land holdings coefficient showed that international migration was much more likely occur among small land holdings and landless community as compared to large land holdings i.e. 13 and more acres. As the possession of land increase by one acre in case of family migration and individual's migration, the probability of staying at origin by. 034323 were take place in both cases. This also implies that large farmer had less tendency of migration as compared to the small farmer and marginal person. Thus, Probit model result showed that land was the main source of 
income in the rural areas of Pakistan.

The analysis of data from eight villages reflected that high rate of international migration from rural areas of Pakistan was intimately associated with unequal distribution of resources (usually land) and law of inheritance in the farming community. It was the main Push factor in the rural areas that was empirically proved. It was further examined that migrants in the rural community whose family was left behind and they were migrated abroad only improve their socio-economic status. It was empirically proved that every migrant /individual seems to come from all income groups to seek the better economic opportunities. As the economic opportunity increased by one unit, the probability of international migration was raised up to .068375 . The findings of the present study also coincide with Lipton's (1980) conclusions regarding the remittances are contributed positively in the household income. Lipton and his other team members of the Indian Village Studies Programme depicted that unequal economic resources was a positive determinants of international migration. "The analysis of data from forty Indian villages reflected that high rate of international migration in Indian villages is intimately associated with unequal distribution of resources (usually land)." Kuhn (1999) concluded that land deprivation, particularly total landlessness without access to any land, is strong determinant of family migration toward abroad while households with some small land holdings are likely to practice individual migration. Stark (1991) argues that relative deprivation plays an important role in international migration decisions. These and several other authors in this area indicate that unequal access and ownership of land and other rural assets lead to movement from the countryside to cities and abroad in search of better economic opportunities. As discussed above, research in Pakistani villages reflected that high rate of international migration from villages is closely associated with unequal distribution of resources, usually land and associated assets.

5.2 The higher rate of poverty reduction among the migrants' families in the rural and urban areas of Pakistan, the greater chance will be likely to the international migration

A large majority of the migrants' families had improved their monthly household income in the urban as well as in the rural areas. The coefficient of monthly income after migration is significant at $1 \%$ level in the urban migrants. The marginal effect of an additional increase in the income by one unit, the probability of poverty reduction is enhanced by .000552 . The result showed that better economic opportunities in Middle East and developed countries were the major source of attraction to the migrants in the Pakistan, which had fascinated the Pakistani people toward the act of migration. While individual migrants whose families left behind his home country had improved their monthly household by sending the remittances because the coefficient of the household monthly income after migration was significant at $10 \%$ level in the rural areas. The additional increase in the income by one unit, the probability of poverty reduction was enhanced by .038180. Probit model result showed that rural out-migration was positively associated with objective of poverty reduction in the urban as well as rural communities. These findings are coincided to a micro-level wages differentiate model which acknowledge migration is more likely if an individual's expected destination-area income, the expected wage timing, the probability of employment, are higher than current origin-area income. So, migration from the lower wages region to the higher wages region is taking place frequently (Harris and Todaro 1970; Todaro 1969).

\section{Conclusions}

Probit model result reflects that in fact people prefer migration to the abroad in order to improve their socioeconomic status i.e. the pull factor, which was a strong determinant of the international migration. Because the coefficient of monthly household income after migration was significant in the urban as well as rural communities. Moreover, Probit model result shows that international migration is positively associated with objective of poverty reduction in the urban as well as rural communities. It was further explored that that family institution was more democratic after international migration international migration in the urban areas as compared to migrants' families left behind in the rural areas because traditional values prevailed in the rural areas. Thus, migration is usually associated with general economic and social development.

\section{References}

Amjad, R. 1989. Economic Impact of Migration to the Middle East on the Major Asian Labour Sending Countries - An Overview', in: R. Amjad, ed., To the Gulf and Back. Studies on the Economic Impact of Asian Labour Migration, Geneva: UNDP/ILO, pp.1-27.

Afsar, R. 1995. Causes, Consequences and Challenges of Rural Urban Migration in Bangladesh, Doctoral Dissertation, University of Adelaide, Australia. 
Bohning, W.R. 1984. Studies in International Labour Migration, London: Macmillan. Chaudhury, R.H. 1980. "Urbanization in Bangladesh, Dhaka", Centre for Urban Studies, University of Dhaka, Bangladesh.

Government of Pakistan 1998. Population and Housing Census of Pakistan, 1998: Census Bulletin-1. Population Census Organization Statistics Division, Islamabad. Government of Pakistan 2002-003. Economic Survey of Pakistan, Islamabad: Economic Advisor Wing, Finance Division, pp.184-85

Harris, J. R. and M. P. Todaro 1970. "Migration, Unemployment and Development, A Sector Analysis" American Economic Review, 60, 60(126-142).

IOM, 2000. World Migration Report. Co published by the International Organization for Migration and the United Nations. Johnson, D.G. 1948. Mobility as a Field of Research. Southern Economic Journal 40:152- 61.

Kuhn, R. 1999. The Logic of Letting Go: Family and Individual Migration from Rural Bangladesh". Unpublished Doctoral Dissertation, University of Pennsylvania, Graduate Group in Demography.

Lee S.B. and J.M. Phillips, 1997. "The Earnings Experience of Rural-Urban Migrants in Korea", International Economic journal 85 Volume 11, Number 4, 1997.

Lipton, M. 1980. Migration from Rural Areas of Poor Countries: The Impact and on Rural Productivity and Income distribution. World Development 8: 1-24.

Mincer, J. 1978. Family Migration Decisions. Journal of Political Economy. 8(2):749-773.

Lipton, M. 1980. Migration from Rural Areas of Poor Countries: The Impact and on Rural Productivity and Income distribution. World development 8: 1-24.

Nachimias, D. and C. Nichimias 1992. Research Methods in Social sciences, (4th edition), New York: St. Martin press. Pp.386-89 Stark, O. 1991. The New Economics of Labor Migration, American Economic Review 75:173-8.

Todaro, M. P. 1969. A Model of Labor Migration and Urban Unemployment in Less-Developed Countries. The American Economic Review: 59 138-148. 